\title{
Dynamics and Distribution of Marine Synechococcus Abundance and Genotypes during Seasonal Hypoxia in a Coastal Marine Ranch
}

\author{
Guihao Li ${ }^{1,2} \oplus$, Qinqin Song ${ }^{3}$, Pengfei Zheng ${ }^{3}$, Xiaoli Zhang ${ }^{3}$, Songbao Zou ${ }^{3}$, Yanfang Li ${ }^{3}$, Xuelu Gao $^{3}$, \\ Zhao Zhao ${ }^{1,2, * \mathbb{B}}$ and Jun Gong ${ }^{1,2,4}$
}

1 School of Marine Sciences, Sun Yat-Sen University, Zhuhai 519082, China; ligh55@mail2.sysu.edu.cn (G.L.); gongj27@mail.sysu.edu.cn (J.G.)

2 Southern Marine Science and Engineering Guangdong Laboratory (Zhuhai), Zhuhai 519000, China

3 Yantai Institute of Coastal Zone Research, Chinese Academy of Sciences, Yantai 264003, China; songqq@idsse.ac.cn (Q.S.); zhengpf@idsse.ac.cn (P.Z.); xlzhang@yic.ac.cn (X.Z.);

songbaozou@gmail.com (S.Z.); yfli@yic.ac.cn (Y.L.); xlgao@yic.ac.cn (X.G.)

4 Guangdong Provincial Key Laboratory of Marine Resources and Coastal Engineering, Guangzhou 510006, China

* Correspondence: zhaozhao5@mail.sysu.edu.cn

check for

updates

Citation: Li, G.; Song, Q.; Zheng, P.; Zhang, X.; Zou, S.; Li, Y.; Gao, X.; Zhao, Z.; Gong, J. Dynamics and Distribution of Marine Synechococcus Abundance and Genotypes during Seasonal Hypoxia in a Coastal Marine Ranch. J. Mar. Sci. Eng. 2021, 9, 549. https://doi.org/10.3390/jmse9050549

Academic Editors: Gabriella Caruso and Carmela Caroppo

Received: 28 February 2021

Accepted: 14 May 2021

Published: 19 May 2021

Publisher's Note: MDPI stays neutral with regard to jurisdictional claims in published maps and institutional affiliations.

Copyright: (c) 2021 by the authors. Licensee MDPI, Basel, Switzerland. This article is an open access article distributed under the terms and conditions of the Creative Commons Attribution (CC BY) license (https:// creativecommons.org/licenses/by/ $4.0 /)$.

\begin{abstract}
Marine Synechococcus are an ecologically important picocyanobacterial group widely distributed in various oceanic environments. Little is known about the dynamics and distribution of Synechococcus abundance and genotypes during seasonal hypoxia in coastal zones. In this study, an investigation was conducted in a coastal marine ranch along two transects in Muping, Yantai, where hypoxic events (defined here as the dissolved oxygen concentration $<3 \mathrm{mg} \mathrm{L}^{-1}$ ) occurred in the summer of 2015. The hypoxia occurred in the bottom waters from late July and persisted until late August. It was confined at nearshore stations of the two transects, one running across a coastal ranch and the other one outside. During this survey, cell abundance of Synechococcus was determined with flow cytometry, showing great variations ranging from $1 \times 10^{4}$ to $3.0 \times 10^{5}$ cells $\mathrm{mL}^{-1}$, and a bloom of Synechococcus occurred when stratification disappeared and hypoxia faded out outside the ranch. Regression analysis indicated that dissolved oxygen, $\mathrm{pH}$, and inorganic nutrients were the most important abiotic factors in explaining the variation in Synechococcus cell abundance. Diverse genotypes (mostly belonged to the sub-clusters 5.1 and 5.2) were detected using clone library sequencing and terminal restriction fragment length polymorphism analysis of the 16S-23S rRNA internal transcribed spacer region. The richness of genotypes was significantly related to salinity, temperature, silicate, and $\mathrm{pH}$, but not dissolved oxygen. Two environmental factors, temperature and salinity, collectively explained $17 \%$ of the variation in Synechococcus genotype assemblage. With the changes in population composition in diverse genotypes, the Synechococcus assemblages survived in the coastal hypoxia event and thrived when hypoxia faded out.
\end{abstract}

Keywords: Synechococcus; summer hypoxia; abundance; genotype; aquaculture

\section{Introduction}

Due to eutrophication and climate change, occurrence of coastal deoxygenation is increasing in strength, duration, and extent [1,2]. The coastal area of aquaculture has been greatly threatened by hypoxia through consequences such as nutrient overload [3] and barrier of water exchange [4]. Microbial taxa are ecologically important in the biogeochemical cycles of biogenic elements and respond to environmental changes sensitively. The correlations of the diversity and abundance of bacterioplankton community with oxygen deficiency have been demonstrated by previous studies of expanding oxygen minimum zones $[5,6]$, and of coastal hypoxic events $[7,8]$. The heterotrophic communities varied under anoxic condition by anaerobic metabolism and high taxonomic diversity occurred 
in anoxic waters $[7,8]$. However, the dynamics of ecotypes or genotypes of important autotrophic microbial taxa with the development of hypoxia remain poorly understood.

Picocyanobacterial Prochlorococcus and Synechococcus are the most abundant photosynthetic prokaryotes on Earth, contributing up to $40 \%$ of marine primary production [9]. Being the second abundant, Synechococcus are widely distributed in the world's oceans [10], sharing broad niches with eukaryotic algae [11] and exhibiting higher abundance in coastal waters than in open oceans [12]. The cell abundance of Synechococcus in subtropical coasts varies among seasons, but is generally lower than $10^{5}$ cells $\mathrm{mL}^{-1}$. The internal transcribed spacer (ITS) region between $16 \mathrm{~S}$ and $23 \mathrm{~S}$ rRNA operons (rDNA) has been widely used as a molecular marker to differentiate subgroups/genotypes within Synechococcus [13-15]. Huang et al. [16] identified four Synechococcus subclusters, namely 5.1A, 5.1B, 5.2, and 5.3, each of which comprised 10, 9, 4, and 6 clades, respectively. It has been demonstrated that these Synechococcus clades occur under specific environmental conditions and at sampling locations, indicating niche partitioning of genotypes. Nutrients and hydrological characters of water masses were assessed to be the main factors driving their spatial and temporal distribution in the surface ocean [11].

The diversity and distribution of Synechococcus have been investigated in varying oxygenation regimes, particularly those of oxygen minimum zones (OMZs) $[15,17,18]$. Synechococcus cells within the OMZ waters of eastern tropical Pacific and Arabian Sea, as determined using flow cytometry, were present in trace concentrations $[15,17,18]$. However, up to $10^{3}$ cells $\mathrm{mL}^{-1}$ were detected in the anoxic/dark waters $(750 \mathrm{~m})$ of the Black Sea [19]. Using terminal restriction fragment length polymorphism (T-RFLP) analysis of ITS rDNA, Lavin et al. [15] discriminated 12 Synechococcus clades in the OMZ of the eastern tropical South Pacific, and detected members belonging to all these genotypes (except for the clade III) in both surface oxic and deeper low-oxygen waters. Differing from these permanent OMZs, seasonal hypoxia usually occurs in estuarine and coastal regions during summer, exhibiting dynamic and periodical variations in dissolved oxygen and other electron acceptors [7]. The cell abundance of Synechococcus decreased with depth during stratification in a seasonally hypoxic site (25 $\mathrm{m}$ in depth) at Devil's Hole, Bermuda [8]. Using PCR amplification of 16S rRNA genes and denaturing gradient gel electrophoresis, Crump et al. [7] detected Synechococcus in both surface and anoxic waters of the Chesapeake Bay. It is evident from these studies that the Synechococcus population might survive in oxygen deficiency. However, little is known about the spatial distribution and dynamics of Synechococcus genotypes and abundance going through seasonal hypoxic events in coastal ecosystems.

In a project on the ecological security of marine ranches, we monitored the dynamics of dissolved oxygen and nutrient concentrations in a coastal marine ranch off Yantai, where hypoxic events occurred in every summer from 2015 through 2017 [20-22]. An intuitive hypothesis was that a combination of thermal stratification and aerobic respiration led to the seasonal hypoxia in bottom waters, and the ranch might have caused deoxygenation in this region. To compare the areal scope relationship between the hypoxic zone and the ranch, surveys were conducted through July to August (2015) in two transects: one running across the ranch zone and the other one was nearby but outside the ranch. The main objective of this study was to explore the spatiotemporal variations in abundance and genotype composition of Synechococcus and their relationships with environmental conditions during the hypoxia events.

\section{Materials and Methods}

\subsection{Sampling and Environmental Data Collection}

The study area was located near Yangmadao, Muping District, Yantai, northern Shandong Peninsula, North Yellow Sea (Figure 1). The maximum depth is about $22 \mathrm{~m}$. Freshwater input from seven streams could affect this area, especially in the rainy season (July and August). It was estimated that scallop excretion contributed to $35.6 \%$ of dissolved inorganic nitrogen and $25.2 \%$ of phosphate influx in this area [23]. The riverine input 
may contribute to the high dissolved organic carbon (DOC) and nutrients in the study area $[20,23]$. The annual thermal stratification occurs from late spring to late summer.

Four cruises (hereafter referred to as Jul-1, Jul-2, Aug-1, and Aug-2) were carried out in the marine ranch area on July 15-17, July 25-27, August 8-11, and August 25-27 of 2015. For each cruise, seawater samples were taken from 14 stations within two transects (Transect 1 and Transect 2), each of which comprised seven stations (Figure 1). At each station, waters from three depths, the surface $(0 \mathrm{~m})$, middle $(10 \mathrm{~m})$, and bottom $(20 \mathrm{~m})$ were collected.

A volume of $100 \mathrm{~mL}$ of the subsample was filtered on board through $0.45-\mu \mathrm{m}$-poresized polyethersulfone membrane filters ( $25 \mathrm{~mm}$ in diameter; Jinteng, Beijing, China), and then stored at $-20^{\circ} \mathrm{C}$ until laboratory analyses for the nutrient analysis. Concentrations of ammonium $\left(\mathrm{NH}_{4}{ }^{+}\right)$, nitrate $\left(\mathrm{NO}_{3}{ }^{-}\right)$, nitrite $\left(\mathrm{NO}_{2}{ }^{-}\right)$, dissolved inorganic phosphorus $\left(\mathrm{PO}_{4}{ }^{3-}\right)$, and dissolved inorganic silicate $\left(\mathrm{SiO}_{3}{ }^{2-}\right)$ were determined using a nutrient AutoAnalyzer (Seal, Germany). Hydrographic data including water temperature, $\mathrm{pH}$, salinity, dissolved oxygen (DO), and chlorophyll $a(\mathrm{Chl}-a)$ were continuously determined in situ using a CTD (SBE 25, Sea-Bird) and YSI sensors, with the precision being $\pm 0.05^{\circ} \mathrm{C}$ (temperature), \pm 0.01 (salinity), $\pm 0.01 \mathrm{mg} \mathrm{L}^{-1}(\mathrm{DO})$, and $\pm 0.01 \mu \mathrm{g} \mathrm{L}^{-1}$ (Chl-a). Meanwhile, a seapoint turbidity meter (Seapoint Sensors, Brentwood, NH, USA) attached to CTD was used to measure the turbidity.

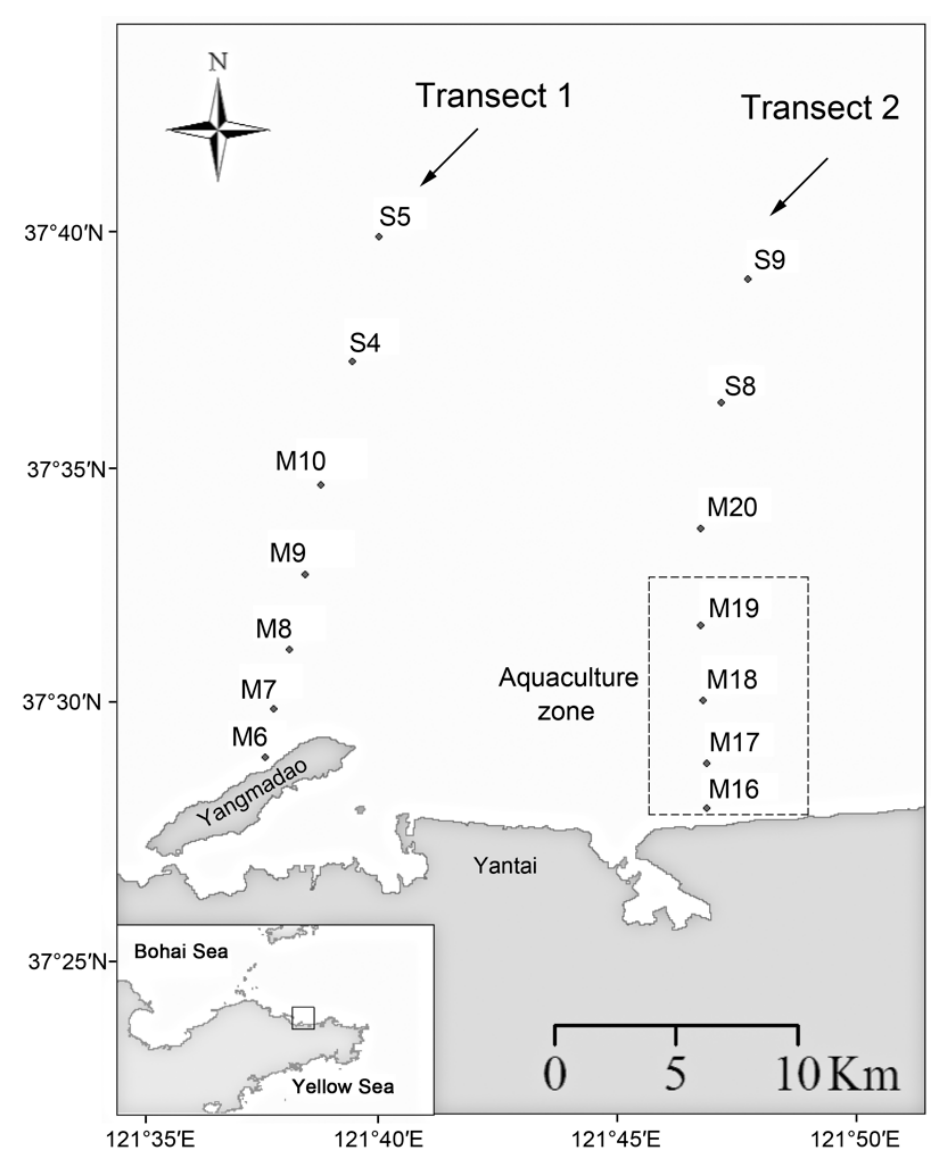

Figure 1. Maps of the study region in a seasonal hypoxia coastal zone showing the locations of the sampling stations along the two transects. The aquaculture zone was showed in the square with dash-lines.

For molecular assays, subsamples (each $300 \mathrm{~mL}$ ) were pre-filtered through a $20 \mu \mathrm{m}$ mesh and then filtered onto $0.22 \mu \mathrm{m}$ polycarbonate filters (Millipore, Germany). The filters with biomass were stored in cryovial tubes at $-80^{\circ} \mathrm{C}$ till use. The pre-filtered subsamples $(2$ $\mathrm{mL}$ ) were taken for flow cytometry analyses, triplicated at each sampling site. The samples 
were fixed with glutaraldehyde at a final concentration of $1 \%(v / v)$ and frozen in liquid nitrogen on board.

\subsection{Flow Cytometry (FCM) Analysis}

The cell abundance of Synechococcus was counted with a BD FACSAria I flow cytometer (BD Biosciences) as previously described [24]. Samples were kept in $-20^{\circ} \mathrm{C}$ under dark for $24 \mathrm{~h}$, then defrosted at room temperature before analysis. Standard fluorescent beads in $1.0 \mu \mathrm{m}$ diameter (Polysciences, USA) were added into the sample in a final concentration of $10^{2}$ cells $\mathrm{mL}^{-1}$. Mixed samples were vortexed for 30-60 s, then kept under dark before sample loading. The orange fluorescence (FL2) and side light scatter (SSC) were used for Synechococcus cell counts $[25,26]$. Data were analyzed with the BD FACSDiva Software.

\subsection{DNA Extraction and T-RFLP Analysis}

The genomic DNA of collected plankton was extracted using the FastDNA Spin Kit according to the instrument of the manufacture (MP Biomedical, Santa Anna, CA, USA). The DNA concentrations were quantified using an ND-2000C spectrophotometer (Thermo Fisher, Waltham, MA, USA). The diversity and composition of Synechococcus genotypes across 118 water samples were assessed using T-RFLP analysis.

For T-RFLP analysis, a fragment containing partial 16S rRNA gene and ITS region was first amplified with the primers DINAf (5'- GAATCTGCCCTCAGGAGGGGG -3') and DINAr (5'- GGGTTGCCCCATTCGGAAAT - $3^{\prime}$ ) [14]. The PCR program was set as follows: $94{ }^{\circ} \mathrm{C}$ for $5 \mathrm{~min}$, followed by 35 cycles of $95^{\circ} \mathrm{C}$ for $1 \mathrm{~min}, 58^{\circ} \mathrm{C}$ for $1 \mathrm{~min}$, and $72{ }^{\circ} \mathrm{C}$ for $2 \mathrm{~min}$, and a final extension at $72{ }^{\circ} \mathrm{C}$ for $10 \mathrm{~min}$. Using the PCR products as templates, a nested PCR approach was executed with the FAM fluorochrome-labeled ITSbF (5'- GTTGGTAGAGCGCCTGCTTTG - $3^{\prime}$ ) and DINAr to target the ITS region located between the Ala tRNA gene and the 23S rRNA gene [14], following the PCR program: denaturation at $94{ }^{\circ} \mathrm{C}$ for $5 \mathrm{~min}$, followed by 35 cycles of $95^{\circ} \mathrm{C}$ for $1 \mathrm{~min}, 56^{\circ} \mathrm{C}$ for $1 \mathrm{~min}$, and $72{ }^{\circ} \mathrm{C}$ for $2 \mathrm{~min}$, and a final extension at $72{ }^{\circ} \mathrm{C}$ for $10 \mathrm{~min}$. The PCR products were purified and digested with the endonuclease AluI (Thermo) at $37^{\circ} \mathrm{C}$ for $2 \mathrm{~h}$ in the dark. The fluorescently labeled terminal restriction fragments (T-RFs) were analyzed using a 3130XL genetic analyzer and GeneScan (v.2.1) software (Applied Biosystems, Foster City, CA, USA). Only the peaks with T-RF lengths $\geq 50 \mathrm{bp}$ were included in the subsequent analysis. The relative abundance of each T-RF was calculated as the ratio of the peak area of that T-RF to the total peak area of all T-RFs detected for a given sample. Minor peaks with a relative abundance of $1 \%$ of the total were excluded, and the remaining peaks were presumed to represent phylotypes of Synechococcus.

\subsection{Clone Library and Sequencing}

In order to link obtained T-RFs to ITS sequence-based genotypes, the water samples collected from three stations (M10 during cruise Jul-1, and M10 and M17 during the cruise Aug-2, respectively) were selected for clone library construction and sequencing of the ITS region. The DNA templates from the surface, middle, and bottom waters were pooled for each station. The ITS region from Synechococcus was PCR amplified with the primers Picocya-16S-F (5'- TGGATCACCTCCTAACAGGG -3') and Picocya-23S-R (5'CCTTCATCGCCTCTGTGTGCC $-3^{\prime}$ ) [27]. A touchdown PCR program was executed as follows: an initial denaturation step at $94^{\circ} \mathrm{C}$ for $5 \mathrm{~min}, 8$ cycles at $94{ }^{\circ} \mathrm{C}$ for $30 \mathrm{~s}, 54-58{ }^{\circ} \mathrm{C}$ for $50 \mathrm{~s}$, and $72{ }^{\circ} \mathrm{C}$ for $1 \mathrm{~min}$, followed by another 30 cycles at $94{ }^{\circ} \mathrm{C}$ for $30 \mathrm{~s}, 55^{\circ} \mathrm{C}$ for $50 \mathrm{~s}$, $72{ }^{\circ} \mathrm{C}$ for $1 \mathrm{~min}$, and a final extension step at $72{ }^{\circ} \mathrm{C}$ for $10 \mathrm{~min}$. The annealing stage was set for $-0.5^{\circ} \mathrm{C}$ per cycle, beginning at $58{ }^{\circ} \mathrm{C}$ with increments to $54{ }^{\circ} \mathrm{C}$.

The amplicons were purified with the Tian Quick Purification Kit (Tiangen, Beijing, China) and cloned into the pTZ57R/T vector (Thermo Fisher, Waltham, MA, USA). The resulting plasmids were transformed into Escherichia coli DH5 competent cells (Tiangen, Beijing, China). The cloned plasmid inserts were amplified directly from the cells using 
M13 vector-specific primers. Approximately 150 clones in each library were randomly selected and sequenced at a sequencing company (Sangon Biotech, Shanghai, China).

\subsection{Phylogenetic Analysis}

The ITS sequences were checked for possible chimeric sequences with Bellerophon [28]. The closely related sequences were identified by BLASTing against the GenBank database and retrieved. The newly obtained and downloaded sequences were then aligned using MAFFT (version 7) [29]. The region encoding for tRNA was too conservative to be phylogenetically informative, thus omitted from the alignment. A maximum likelihood (ML) tree was constructed using RaxML 8.0 with the best GTRGAMMAI model and a bootstrap analysis of 1000 replications [30]. A Bayesian tree was generated using MrBayes 3.2.6.

\subsection{Statistical Analysis}

Student's $t$-tests (two-tailed) and one-way ANOVA were performed to test the differences in cell abundance of Synechococcus and environmental factors among different cruises and depth layers. Regression analysis was conducted to explore the associations between the (log-transformed) cell abundance of Synechococcus, diversity indices and environmental variables. All these analyses were performed using software SPSS (v.20.0) for Windows (SPSS, Chicago, IL, USA).

Multidimensional scaling (MDS) was performed based on the T-RFLP results using package PRIMER (v.6) (Primer-E, United Kingdom). Analysis of similarity (ANOSIM) was conducted to statistically test the differences in the Synechococcus assemblage. Detrended correspondence analysis was executed to determine the length of the environmental gradient using CANOCO (v.4.5), then canonical correspondence analysis (CCA) was selected to explore the environment-biota relationships.

\section{Results}

\subsection{Environmental Conditions}

Overall, the environmental variables in the marine ranch varied greatly during the surveys (Figure 2; Figure S1). For both transects, from the late July to early August, the water column was thermally stratified, with a temperature gradient from the bottom (20.2 $\pm 0.3^{\circ} \mathrm{C}$, mean $\pm \mathrm{SE}$ ), middle layer $\left(22.7 \pm 0.2{ }^{\circ} \mathrm{C}\right)$, to surface $\left(26.1 \pm 0.2^{\circ} \mathrm{C}\right)$. However, in Aug-2, stratification weakened greatly in late August, displaying similar temperatures $\left(24.9 \sim 25.6{ }^{\circ} \mathrm{C}\right)$ throughout the water column in Transect 1 and $24.3 \sim 26.1^{\circ} \mathrm{C}$ in Transect 2. Similarly, for both transects, the salinity was $30.1 \pm 0.2$ in surface water, which was lower than that in the middle $(31.2 \pm 0.1)$ and bottom $(31.3 \pm 0.1)$ in late July and early August $(p$ $<0.001$ ). In late August, the distribution of salinity was uniform (around 30.7, Figure S1). 


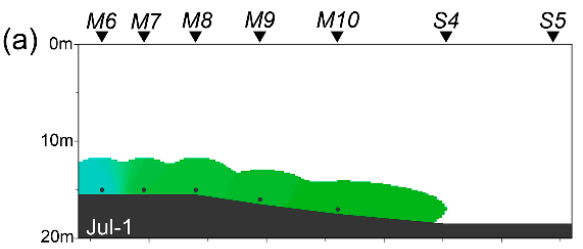

(c)

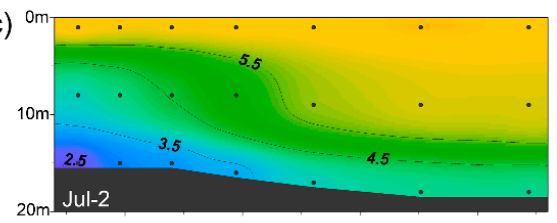

(e)

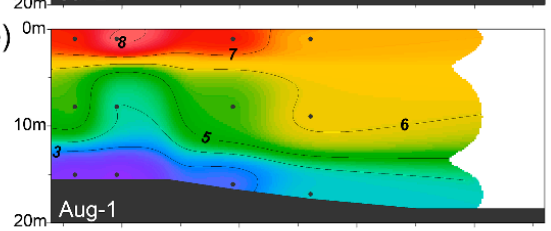

(g)

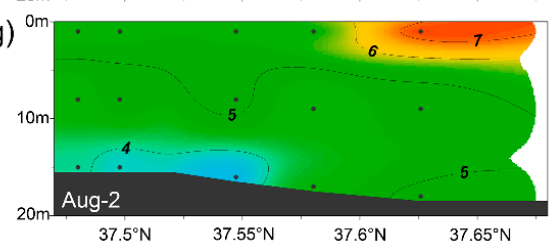

(b)

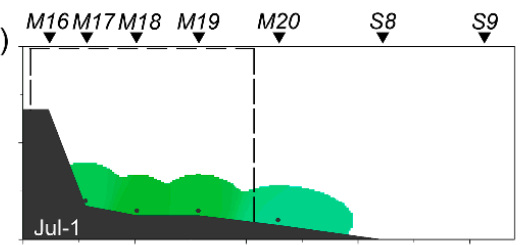

(d)

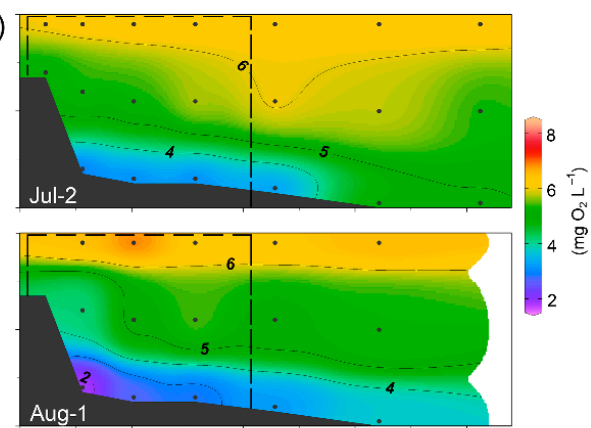

(h)

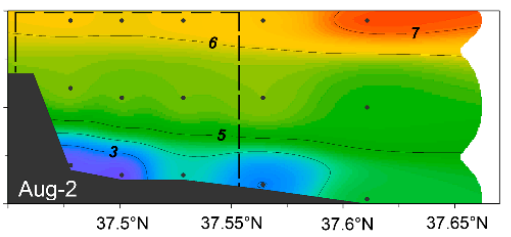

Figure 2. Vertical profiles of dissolved oxygen along Transects 1 (left panel, $(\mathbf{a}, \mathbf{c}, \mathbf{e}, \mathbf{g})$ ) and 2 (right panel, $(\mathbf{b}, \mathbf{d}, \mathbf{f}, \mathbf{h}))$ during four cruises in the middle (Jun-1, (a, $\mathbf{b}))$ and late July $(J u l-2,(\mathbf{c}, \mathbf{d}))$, and early (Aug-1, (e,f)) and late August (Aug-2, (g,h)) of 2015. Triangles along the uppermost margins indicate the positions of sampling stations. The dashed boxes refer to the location of ranching zone $(\mathbf{b}, \mathbf{d}, \mathbf{f}, \mathbf{h})$.

The DO generally decreased with depth (surface: $6.3 \pm 0.1 \mathrm{mg} \mathrm{L}^{-1}$; middle layer: 5.2 $\pm 0.1 \mathrm{mg} \mathrm{L}^{-1}$, and bottom water: $3.4 \pm 0.2 \mathrm{mg} \mathrm{L}^{-1}$ ). In the middle of July, the bottom $\mathrm{DO}$ was $4.28 \pm 0.1 \mathrm{mg} \mathrm{L}^{-1}$, and became hypoxic $\left(\mathrm{DO}<3 \mathrm{mg} \mathrm{L}^{-1}\right)$ in late July (Figure $2 \mathrm{c}$,d). Spatially, this hypoxic zone maximized in early August and occupied a large area spanning both transects (Figure 2e,f). Nevertheless, in late August, the bottom hypoxia started to fade out along Transect 1, where DO increased to levels higher $3.5 \mathrm{mg} \mathrm{L}^{-1}$, while deoxygenation remained at Transect 2 (Figure $2 \mathrm{~g}, \mathrm{~h}$ ). For both transects, the $\mathrm{pH}$ ranged from 7.44 to 8.26 , with significantly lower values in the bottom layer $(7.83 \pm 0.02)$ than the surface $(8.04 \pm 0.01)$ and middle depth $(8.03 \pm 0.01)$. Temporally, the water became acidified in late July ( $\mathrm{pH} 7.97 \pm 0.02)$ and early August $(7.84 \pm 0.03)$, and returned to $8.08 \pm 0.02$ throughout the water column (Figure S1). Furthermore, there was no significant differences in $\mathrm{pH}$ between Transect 1 and Transect 2.

Overall, the concentrations of nutrients, especially $\mathrm{SiO}_{3}{ }^{2-}$ and $\mathrm{NH}_{4}{ }^{+}$, were higher in the bottom than in the overlying waters. The concentration of $\mathrm{SiO}_{3}{ }^{2-}$ were relatively low $(3.8 \sim 4.5 \mu \mathrm{M})$ in July and early August, but became higher $(6.6 \pm 0.6 \mu \mathrm{M})$ in late August. In contrast, there were generally lower levels of $\mathrm{NO}_{2}{ }^{-}$and $\mathrm{PO}_{4}{ }^{3-}$ through late July to the whole of August. There were no significant differences in concentration of $\mathrm{SiO}_{3}{ }^{2-}$ and $\mathrm{NO}_{2}{ }^{-}$between Transect 1 and Transect 2, while $\mathrm{NH}_{4}{ }^{+}$and $\mathrm{PO}_{4}{ }^{3-}$ were higher in Transect $1(2.8 \pm 0.4$ and $0.32 \pm 0.02 \mu \mathrm{M}$, respectively) than in Transect $2(2.0 \pm 0.3$ and $0.29 \pm 0.01$ $\mu \mathrm{M}$, all $p<0.05)$. The distribution of $\mathrm{NO}_{3}{ }^{-}$was rather irregular during the four cruises (Figure S1) and there was no difference between Transect 1 and Transect 2.

The Chl- $a$ concentration was often higher in the middle layer $\left(6.0 \pm 0.5 \mu \mathrm{g} \mathrm{L}^{-1}\right)$ than those in the surface $\left(2.5 \pm 0.3 \mu \mathrm{g} \mathrm{L}^{-1}\right)$ and bottom $\left(1.9 \pm 0.2 \mu \mathrm{g} \mathrm{L}^{-1}\right)$. High levels of Chl- $a$ were observed in late July $\left(4.4 \pm 0.7 \mu \mathrm{g} \mathrm{L}^{-1}\right)$, when the hypoxia took place. Unlike Chl-a, the bottom water had much higher turbidity $(20.0 \pm 3.9 \mathrm{NTU})$ than the middle $(4.4 \pm 1.1$ NTU) and the surface waters $(1.9 \pm 0.1$ NTU) $(p<0.001$; Figure S1). No difference was found in Chl- $a$ and turbidity between Transect 1 and Transect 2 (all $p>0.05$ ). 


\subsection{Cell Abundance of Synechococcus}

The cell abundance of Synechococcus ranged from $0.10 \times 10^{4}$ to $31.10 \times 10^{4}$ cell mL $\mathrm{m}^{-1}$ (Figure 3). In the middle of July, Synechococcus cell abundance was $(0.74 \pm 0.09) \times 10^{4}$ cells $\mathrm{mL}^{-1}$, showing little vertical variations in both transects (Figure 3a,b). When hypoxia occurred in later July, the cyanobacteria became more abundant in the middle and bottom layers than that in the surface (Figure 3c,d). When the bottom hypoxia was more severe in early August, the Synechococcus abundance $\left[(1.81 \pm 0.31) \times 10^{4}\right.$ cells $\left.\mathrm{mL}^{-1}\right]$ did not change much throughout the water column (Figure 3e,f). As time went by and the DO level increased to above $3 \mathrm{mg} \mathrm{L}^{-1}$ in the bottom, however, Synechococcus bloomed in late August, with a mean cell abundance of $(9.53 \pm 1.62) \times 10^{4}$ cells mL ${ }^{-1}$ (Figure 3g,h). In the meantime, Synechococcus was also more abundant in Transect 1 than in Transect 2, where hypoxia in the area of ranching remained (Figure $3 \mathrm{~g}, \mathrm{~h}$ ).

(a)

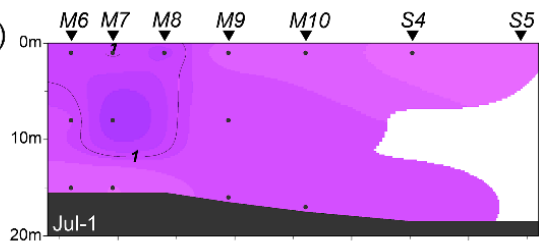

(c)

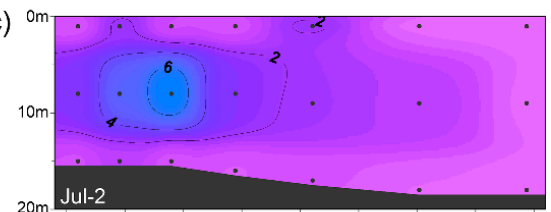

(e)

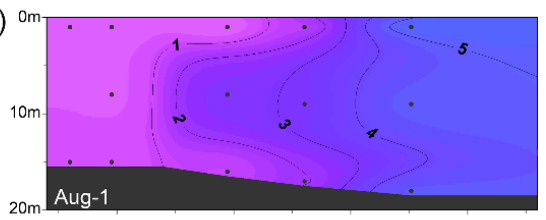

(g)

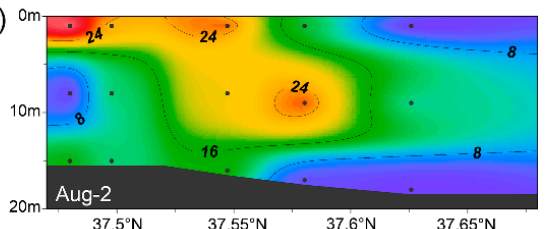

(b)

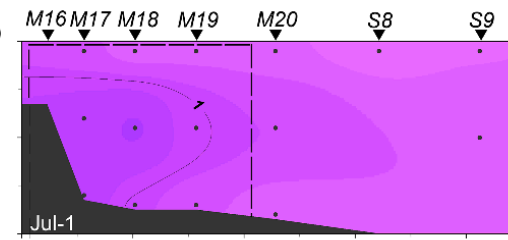

(d)

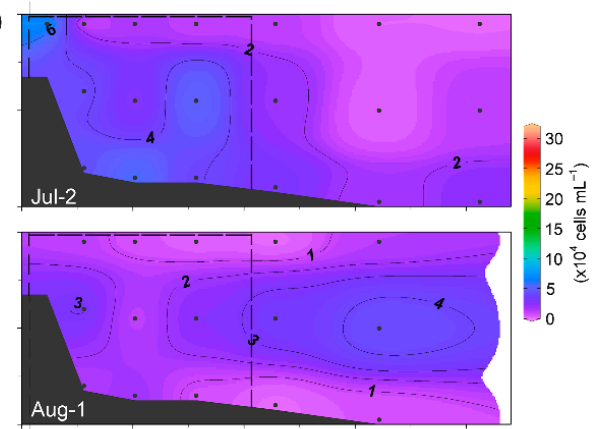

(h)

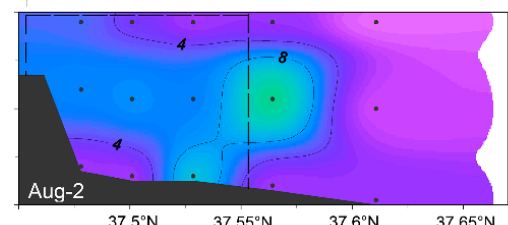

Figure 3. Vertical profiles of Synechococcus cell abundance along Transects 1 (left panel, $(\mathbf{a}, \mathbf{c}, \mathbf{e}, \mathbf{g})$ ) and 2 (right panel, $(\mathbf{b}, \mathbf{d}, \mathbf{f}, \mathbf{h})$ ) during four cruises in middle (Jun-1, (a,b)) and late July $(J u l-2,(\mathbf{c}, \mathbf{d}))$, and early (Aug-1, e,f) and late August (Aug-2, (g,h)) of 2015. Triangles along the uppermost margins indicate the positions of sampling stations. The dashed boxes refer to the location of the ranching zone $(\mathbf{b}, \mathbf{d}, \mathbf{f}, \mathbf{h})$.

Both linear and nonlinear regression analyses identified $\mathrm{DO}, \mathrm{pH}, \mathrm{PO}_{4}{ }^{3-}, \mathrm{SiO}_{3}{ }^{2-}$, salinity, and $\mathrm{NH}_{4}{ }^{+}$were the most significant environmental factors driving the Synechococcus abundance $(p<0.05$; Figure 4). Among these, both $\mathrm{pH}$ and DO explained the highest percentages $(21 \%)$ of the variance of Synechococcus abundance. Nevertheless, Synechococcus abundance peaked in intermediate levels $\left(\sim 4.5 \mathrm{mg} \mathrm{L}^{-1}\right)$ of $\mathrm{DO}$, but at the highest levels of $\mathrm{pH}$. The relationships between the Synechococcus abundance and $\mathrm{PO}_{4}{ }^{3-}$ and $\mathrm{SiO}_{3}{ }^{2-}$ were parabolic, which explained $14.8 \%$ and $13.1 \%$ of the variance, respectively $(p<0.003$, Figure 4$)$. The impact of salinity and $\mathrm{NH}_{4}{ }^{+}$were relatively low, accounting for $9.3 \%$ and $7.6 \%$ of the variance in Synechococcus abundance $(p<0.05)$. The Synechococcus abundance decreased with turbidity, but the correlation was weak and insignificant $\left(R^{2}=0.043, p=0.09\right.$; Figure 4). The relationship between Chl- $a$ and Synechococcus abundance appeared to be positive, but not significant $\left(R^{2}=0.018, p>0.05\right.$; Figure 4). 

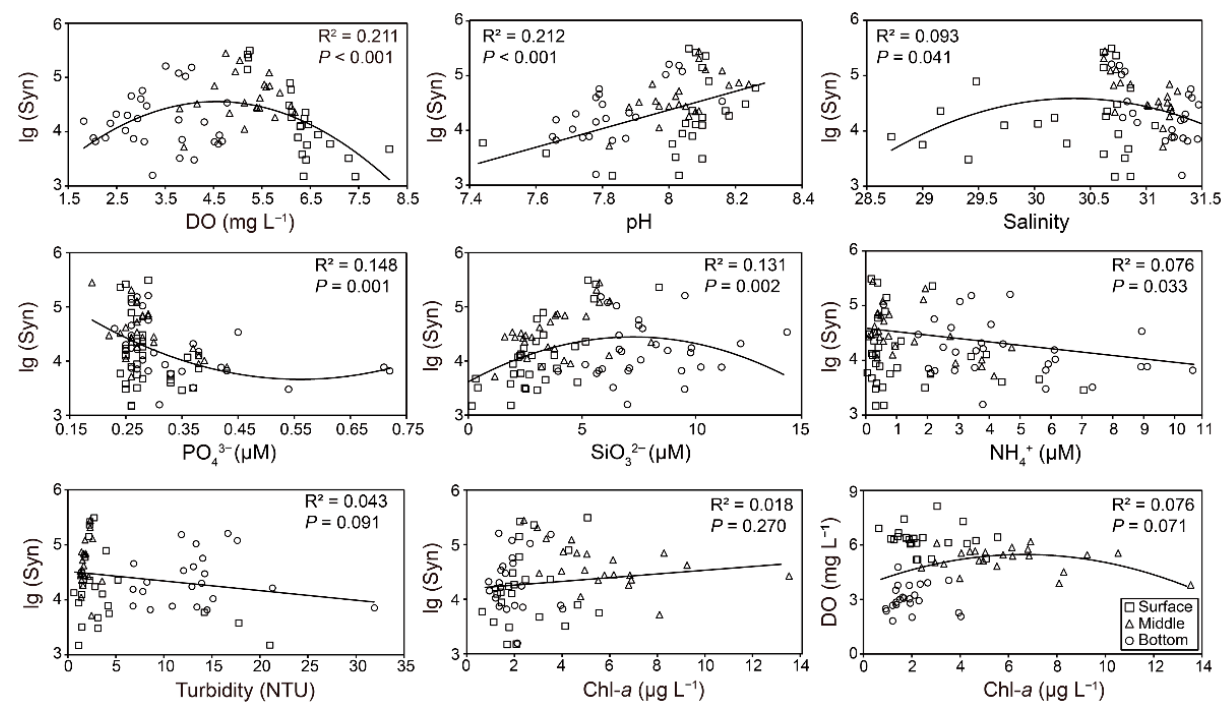

Figure 4. Regression analyses showing the relationships between log transformed cell abundance of Synechococcus (cell $\mathrm{mL}^{-1}$ ) and environmental factors. The relationship between dissolved oxygen $\left(\mathrm{DO}, \mathrm{mg} \mathrm{L}^{-1}\right)$ and chlorophyll concentration $(\mathrm{Chl}-a)$ is also shown. Only the important results are reported.

\subsection{Richness and Composition of Synechococcus Genotypes}

A total of 333 ITS sequences were obtained from the three clone libraries, with 110 from station M10 in mid-July, 115 from station M10, and 108 from station M17 in late August. The coverage of these clone libraries was $91.8 \%, 84.4 \%$, and $85.2 \%$, respectively, showing that most Synechococcus genotypes had been recovered. Both the ML and Bayesian trees based on the ITS sequences showed identical topologies (Figure 5). The sequences newly obtained from this study clustered into nine clades, according to Huang et al. [16]. These included clades I, IV, and II (subcluster 5.1A), clades CB1, CB2, VIII, CB3, and V (subcluster 5.1B), and CB5 (subcluster 5.2) (Figures 5 and 6a). The diversity and assemblage composition of Synechococcus genotypes were assessed using T-RFLP for all 118 samples. A total of 72 distinct T-RFs were identified. The number of Synechococcus T-RFs in each sample varied from 6 to 20, with significantly higher levels in late August (on average 16) than the others $(p<0.01)$. Nevertheless, the differences between the surface, middle, and bottom layers were not significant (Figure $6 b$ ).

The MDS plot of early July to late August shows the largest changes observed between Jul-1 and Aug-2 (Figure 6d). The ANOSIM statistical analysis supported the significant differences among the four cruises $(R=0.59, p<0.01$, Table S1), and between Jul- 1 and Aug-2 $(R=0.97, p<0.01$, Table S1).

The ITS sequences of genotypes were digested in silico using the restrict endonuclease AluI (i.e., cleaving at the sites $5^{\prime}-\mathrm{AG} / \mathrm{CT}-3^{\prime}$ ), and the resulting T-RFs were then assigned to represent the corresponding clades/genotypes, as previously described [14]. This allowed us to characterize the variations in genotype composition across all 118 water samples (Figure 6c). The genotype composition of Synechococcus varied among sampling cruises, water layers, and transects. In mid-July, clade I dominated the Synechococcus assemblage, accounting for more than $60 \%$ relative abundance across depths and transects. Clade IV was much more abundant $(16.9 \%)$ in the surface waters in Transect 2 than those in the other layers and Transect $1(<2 \%)$. In contrast, clades VI and CB2 had higher proportions in the middle (3.6\% and $0.3 \%$, respectively) and bottom layers $(4.0 \%$ and $1.1 \%)$ than that in the surface $(3.0 \%$ and $0.0 \%)$. Clade CB5 accounted for $2.6 \%$ in the bottom, which was lower than those in the surface $(11.4 \%)$ and middle waters $(9.6 \%)$. 


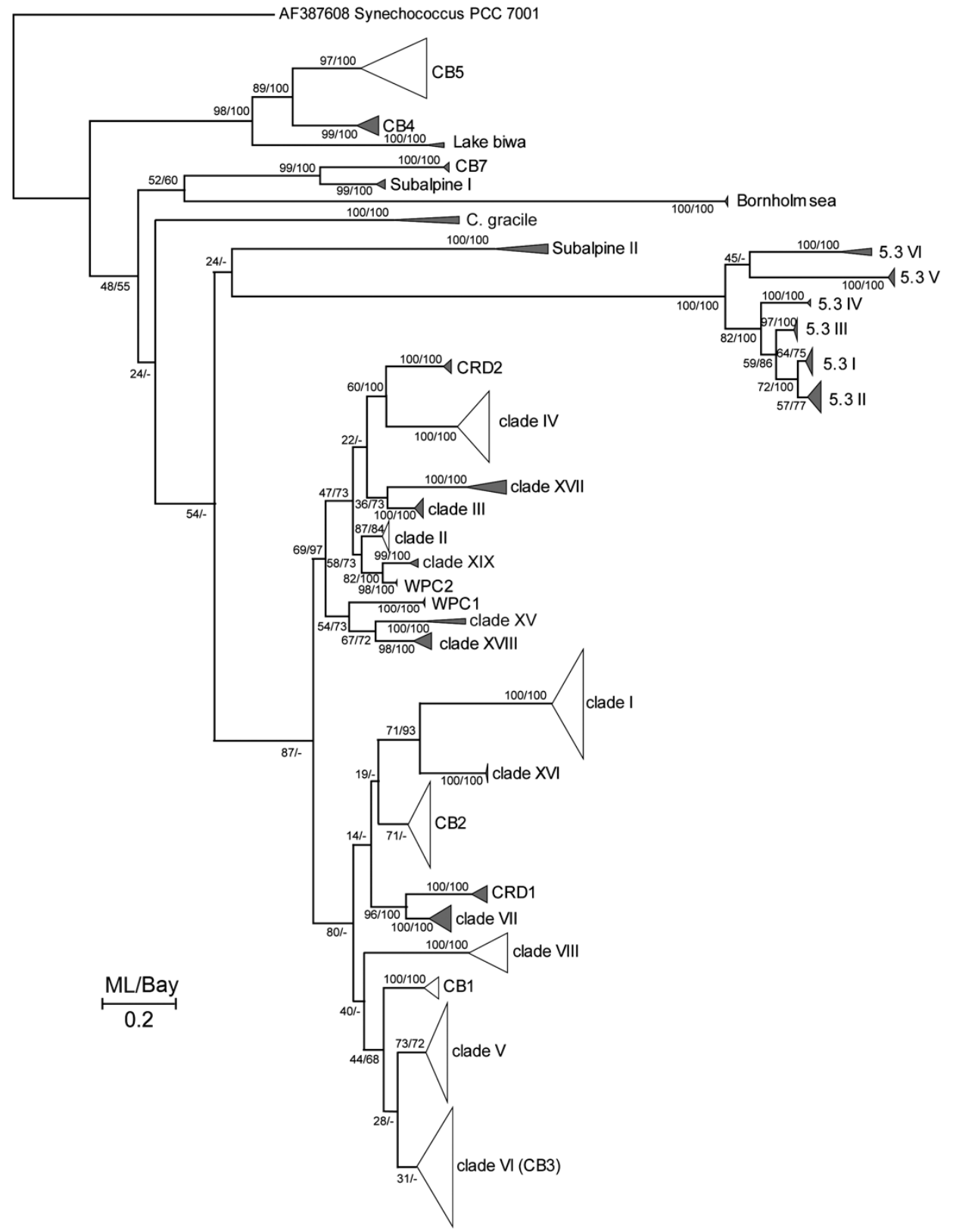

Figure 5. A phylogenetic tree of the Synechococcus internal transcribed spacer (ITS) region of 16S$23 \mathrm{~S}$ rDNA sequences, showing consensus topology obtained using maximum likelihood (ML) and Bayesian inference. The ITS sequence of strain PCC 7001 was used as the out-group. Open triangles indicate that the clades included sequences newly obtained in the present study. Both bootstrap values of ML and posterior probability (Bay) are shown at the nodes in percentage. Only nodal supports higher than $50 \%$ are shown. The scale bar indicates 20 nucleotide substitutions per 100 sites.

In late July, CB1 became more abundant in the Synechococcus assemblages, with relative abundance increasing from the surface $(6.5 \%)$ to bottom $(21.7 \%)$. In the early of next month, CB5 became dominant across all depths and transects ( $>27 \%)$. CB1 had a higher proportion in Transect 2 in the middle and bottom layers. Nevertheless, this genotype was rare in Transect 1 and surface water $(0.0 \%)$. In late August, the major clades seemed to be homogeneously distributed in the water column and across these two transects (Figure 6c). 
(a)

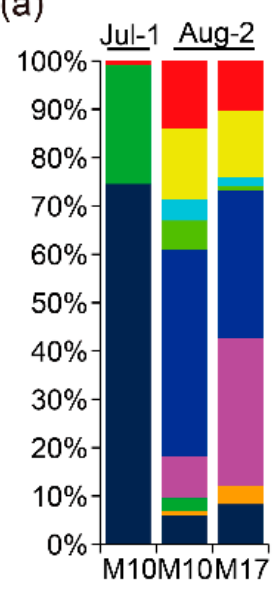

(c)
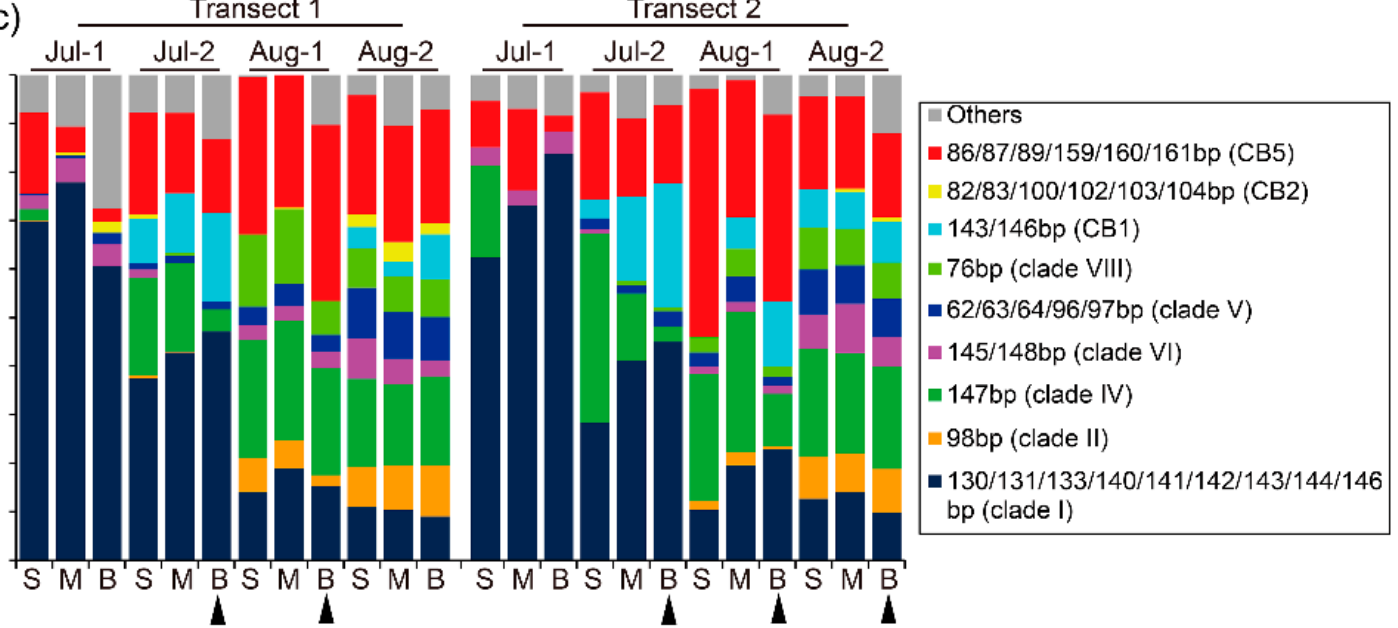

(d)

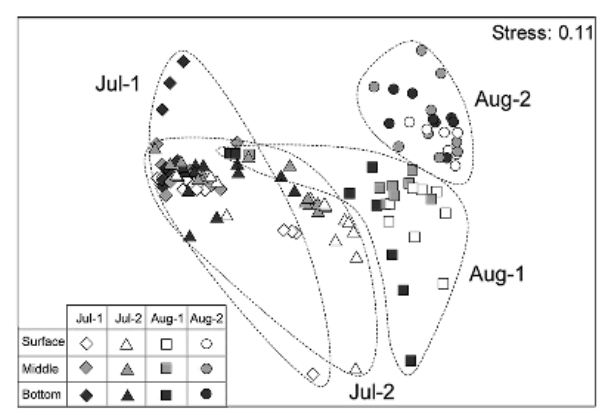

Figure 6. Variations of the Synechococcus genotypes along the two transects during four cruises across all depth from the result of clone library (a) and T-RFLP (c). S: surface, M: middle, B: bottom. The black triangles indicate the hypoxic layer. And variations in the number of terminal restriction fragments (T-RFs) of the Synechococcus 16S-23S internal transcribed spacer of rDNA are also shown (b). Box plots showing T-RF richness were similar among the surface, middle, and bottom layers, but significantly higher in late August (Aug-2) cruises than other samples collected in middle (Jul-1) and late July (Jul-2) and early (Aug-1) (b). Different letters in (b) indicate significant differences $(p<0.05)$. The multidimensional scaling plot showing differences in genotype assemblages $(\mathbf{d})$.

\subsection{Relationships between Genotype Richness and Assemblage of Synechococcus and Environmental Factors}

Among all the determined environmental factors, salinity $\left(R^{2}=0.241\right)$ and temperature $\left(R^{2}\right.$ $=0.156)$ were significantly related to with the number of T-RFs $(p<0.01$; Figure $7 \mathrm{a})$. The number of T-RFs peaked at the intermediate salinity or at the highest levels of temperature (Figure 7a). Furthermore, T-RF richness was positively correlated with $\mathrm{SiO}_{3}{ }^{2-}\left(R^{2}=0.135, p<0.001\right)$, and established a U-shape relationship with $\mathrm{pH}\left(R^{2}=0.131, p=0.01\right)$ (Figure 7a). Nevertheless, no significant correlation was observed between T-RF richness and turbidity $\left(R^{2}=0.001, p=0.932\right)$.

The plot of CCA showed that the assemblage of Synechococcus genotypes covaried significantly with temperature $(p=0.005)$, salinity $(p=0.010)$, and the concentration of $\mathrm{SiO}_{3}{ }^{2-}(p=0.010)$. The three factors collectively explained $20 \%$ of the assemblage variation (Figure $7 \mathrm{~b}$ ).

The CCA plot showed that temperature $(p=0.005)$, salinity $(p=0.025)$, the concentrations of $\mathrm{SiO}_{3}{ }^{2-}(P=0.005)$, and $\mathrm{NH}_{4}{ }^{+}(P=0.010)$ were major factors shaping the distribution of nine Synechococcus genotypes (Figure 7c). Clade I was more abundant at lower temperatures, whereas other genotypes were richer at higher temperatures. Furthermore, clades VIII, IV, and CB5 were highly presented at lower salinity and $\mathrm{NH}_{4}{ }^{+}$concentration (Figure 7c). 
(a)
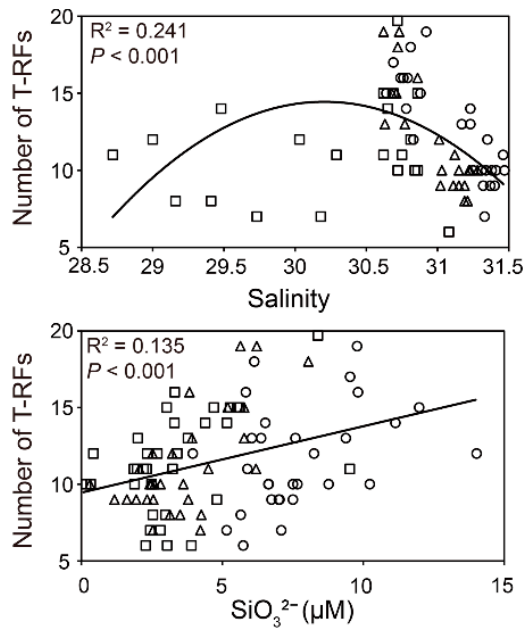

(b)

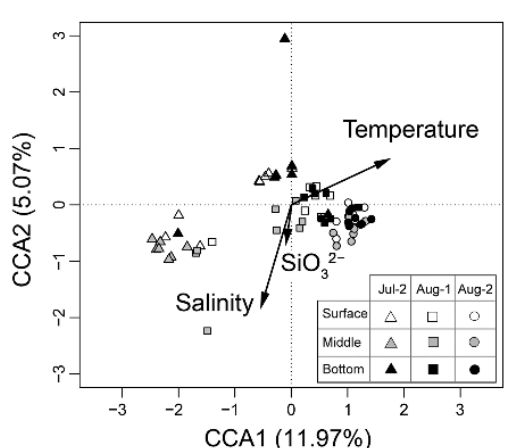

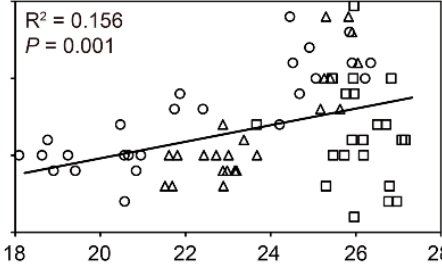
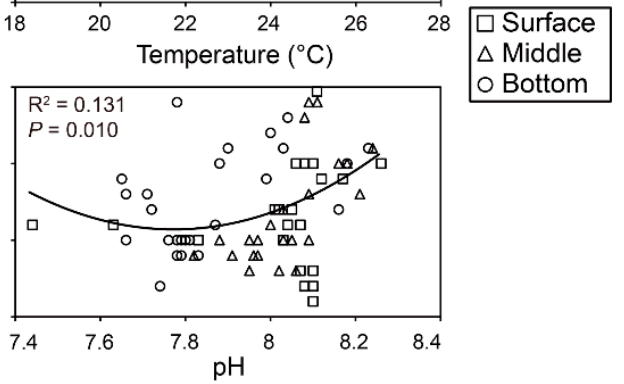

(c)

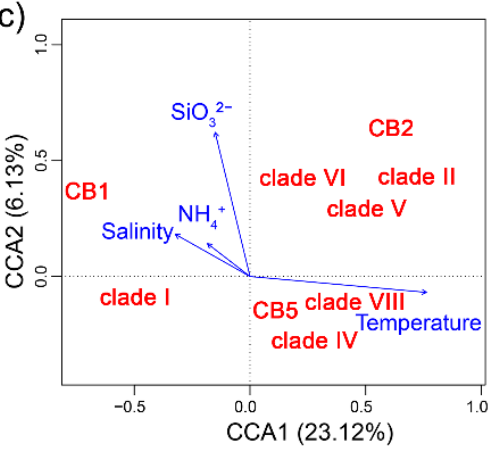

Figure 7. The regression relationships between T-RF richness and four mostly important environmental factors (a). The canonical correspondence analysis (CCA) plots in which the genotype assemblages were based on the relative abundance of each T-RF (b), and of major genotype clades (c) recovered during the cruises Jul-2, Aug-1, and Aug-2. The symbols in different colors and shapes indicate water layers and sampling cruises, respectively.

\section{Discussion}

Our surveys of the three depths in the shallow water columns in the Muping ranch revealed that there were great temporal and spatial variations in abiotic and biotic variables from July through August 2015. In particular, we observed the occurrence of hypoxic events in the bottom water in the late July and early August. The obtained DO data consistently showed that the hypoxia was confined to the area close to the shore, regardless of the transects running outside or across the ranching zone (Figure 2). This may indicate little evidence for a causal relationship between hypoxia and aquaculture in the studied area. Nevertheless, the bottom hypoxia persisted for a longer time in the ranching zone (within Transect 2) than that of Transect 1 in late August, suggesting that the ranching contributed, to some extent, to the seasonal hypoxia. Due to the lack of in situ data such as ocean currents and winds, this assumption needs to be further tested.

The low concentrations of DO in bottom waters were undoubtedly due to microbial consumption of dissolved oxygen, especially to heterotrophic bacteria [7,8], which might, in turn, influence the autotrophs including Synechococcus. The Synechococcus population varied during the surveys with changes of cell abundance and the composition of genotypes.

Interestingly, we observed a bloom of Synechococcus abundance when the hypoxia faded away at the nearshore stations of Transect 1 in late August (Figure $3 g$ ). The abundance in this study was up to $3 \times 10^{5}$ cells $\mathrm{mL}^{-1}$, which was three times higher than the record of global surveys across coastal and oceanic regions [31]. A number of physical and chemical factors have been suggested as contributors to the success of Synechococcus. These included high residence time [32], warm water temperature [33,34], bio-availability of nutrients, especially phosphorus $[35,36]$. In our study, high abundance of Synechococcus occurred 
in Transect 1 in Aug-2 when the water column became vertically well-mixed which the temperature and salinity were uniform across all water layers (Figure 2g and Figure S1). The mixing of water column could bring nutrients accumulating at the bottom layer to the surface and middle waters; meanwhile, the microbes in the bottom sinking from surface waters were also re-exposed to the light with this process. However, there were no significantly positive correlations between the nutrients measured in our study (i.e., $\mathrm{PO}_{4}{ }^{3-}$, $\mathrm{NH}_{4}{ }^{+}$and $\mathrm{NO}_{3}{ }^{-}$) and Synechococcus abundance. It even presented negative correlations between $\mathrm{PO}_{4}{ }^{3-}$ and $\mathrm{NH}_{4}{ }^{+}$and Synechococcus abundance within a certain range (Figure 4). Synechococcus has an advantage in nutrient uptake capacity over larger phytoplankters due to small size [37], so the nutrients in the water might be quickly absorbed by Synechococcus, thus we observed a high abundance of them accompanied with a low concentration of nutrients (Figure 4). Although we did not have the data of light intensity, it has been proved to be one of the most important factors that control the distribution of Synechococcus $[12,31]$ and is suggested to be a factor that favors the dominance of Synechococcus in the shallow region $(<3.0 \mathrm{~m})$ of Florida Bay [34]. Callieri et al. [19] revealed that one strain of Synechococcus could accumulate the Chl- $a$ in anoxic/dark conditions and had the capacity to photosynthesize when re-exposed to light. We suggested that Synechococcus, which may accumulate a large amount of Chl- $a$ in the bottom water with low light fluxes, showed explosive growth when it was re-exposed to light through water mixing.

Across all four cruises (Jul-1, Jul-2, Aug-1, and Aug-2), we found that DO, along with $\mathrm{pH}$, were the most significant environmental variables relating to the cell abundance dynamics of Synechococcus (Figure 4). Given that photoautotroph Synechococcus are oxygen producers and should not be directly affected by oxygen availability, the humpbacked relationship observed between Synechococcus abundance and DO might reflect a consequence of trade-off in at least two major forces that controlled the Synechococcus abundance variations. The lowest $\mathrm{DO}$ levels were all found in the bottom layers where nutrients were rich, but low availability of light might have constrained the growth of Synechococcus. In the surface layers, though there was enough irradiance for photosynthetic production, competition with pigmented eukaryotes for nutrients and intensive top-down pressure (protozoan grazing and viral lysis) might have resulted in low standing stock of the picocyanobacteria [38-41]. In contrast, the highest Synechococcus abundance was likely due to intermediate bottom-up and top-down controls in the middle layers, coinciding with the intermediate DO levels.

The positive correlation between Synechococcus and $\mathrm{pH}$ might reflect the contribution of cyanobacterial photosynthesis, which consumed dissolved $\mathrm{CO}_{2}$, and decreased $\left[\mathrm{H}^{+}\right]$ and bicarbonate concentration in the water. Similarly, the negative relationship between Synechococcus abundance and $\mathrm{PO}_{4}{ }^{3-}$ might be due to their nutrient uptake for photosynthetic production. Lower silicate levels could be a consequence of silicate uptake by diatoms, which enables diatom outcompete Synechococcus for other nutrients (e.g., $\mathrm{PO}_{4}{ }^{3-}$ ), leading to the positive correlation between silicate and Synechococcus abundance in surface and middle layer depths.

The dynamics of richness and assemblage composition of Synechococcus genotypes and its driving factors were also explored. We found that temperature and salinity were the most important environmental factors in our measured variables, which influenced the community succession of Synechococcus (Figure 7a,b). This result is consistent with previous work demonstrating the importance of temperature and salinity or water mass in controlling the richness and composition of Synechococcus assemblages in Chesapeake Bay [27], coastal waters of Hong Kong [42], South Pacific to the Arctic Ocean [43], and global oceans [16]. The Synechococcus sub-cluster 5.2 comprises mostly halotolerant strains isolated from coastal waters and all members of sub-cluster 5.1 have elevated salt $\left(\mathrm{Na}^{+}\right.$, $\mathrm{Cl}^{-}, \mathrm{Mg}^{++}$and $\left.\mathrm{Ca}^{++}\right)$requirements for growth [38,44], which explains the increase of Synechococcus genotype richness with salinity, typically within a relatively lower range (i.e., salinity < 30.5) (Figure 7a). When salinity > 30.5, the richness progressively decreased, 
suggesting that most of these ecotypes were inhibited at higher levels of salinity, except for clade VIII, which can survive in saline waters $[16,45]$.

Our study showed niche adaption of many Synechococcus genotypes (Figure 7c). Among all genotypes detected in this study, only two clades, I and CB1, had higher relative abundances at lower temperatures. This is in line with previous studies showing that these two genotypes often occur in temperate to polar waters roughly above $30^{\circ} \mathrm{N} / 30^{\circ} \mathrm{S}$ and were cold-adapted genotypes [16,33,46-50]. The remaining genotypes such as clades II, $\mathrm{V}, \mathrm{VI}$, and VIII, are known to be temperature-tolerant or frequently occur under warm conditions [38,47,51]. CB1, CB2, and CB5 also dominated Synechococcus populations in the Chesapeake in summer (temperature from $23.9{ }^{\circ} \mathrm{C}$ to $27.3{ }^{\circ} \mathrm{C}$ ) [27]. Nevertheless, we found that clade IV had higher relative abundance at a relatively high temperature (Figure 7c), which is in contrast with previous inference that this genotype was cold-adapted [16,51,52]. In fact, a strain of clade IV was also found to be rich in the river mouth of Kwangyang Bay in summer $\left(24^{\circ} \mathrm{C}\right)$ [44]. Therefore, high availability of nutrients may be a contributor to relatively high abundances of clade IV under a warm condition [51].

Although temperature, salinity, and $\mathrm{SiO}_{3}{ }^{2-}$ were the most important factors that controlled the variations in Synechococcus population in our study during hypoxia (Figure 7b), a large proportion remained unexplained (up to $83 \%$ ). Very likely, other environmental factors not measured in this study, for example, light availability and physical processes, played an important role in structuring the Synechococcus genotypes in coastal environments. Furthermore, the top-down controls including grazing and viral lysis were not counted, which had an essential impact on the growth and population variation of Synechococcus [40,41]. Allelopathic activity of Synechococcus sp. was found in fresh waters [53-55], but few evidences were found in marine strains, which might also be an importance influence of the Synechococcus population dynamics when competing with other phytoplankton. The relative importance of abiotic and biotic factors in controlling ecotypes of these picocyanobacteria has to be further investigated.

Supplementary Materials: The following are available online at https:/ /www.mdpi.com/article/10 $.3390 / j m s e 9050549 / \mathrm{s} 1$, Figure S1: Variations of environmental factors among three depths. S: surface, M: middle, B: bottom. Table S1: Results of ANOSIM testing the differences in assemblage structure of Synechococcus genotypes at separate sampling cruises.

Author Contributions: Conceptualization, J.G., X.Z., and Z.Z.; Methodology, Q.S., X.G., and Y.L.; Software, G.L.; Formal analysis, G.L. and Q.S.; Investigation, G.L., P.Z., and S.Z.; Data curation, J.G.; Writing—original draft preparation, G.L., Z.Z., and Q.S.; Writing—-review and editing, J.G. and Z.Z.; Project administration, J.G.; Funding acquisition, J.G. All authors have read and agreed to the published version of the manuscript.

Funding: This research was funded by the Strategic Priority Research Program of the Chinese Academy of Sciences (Nos. XDA23050303 and XDA11020702), the Key Research Project of Frontier Science, CAS (No. QYZDB-SSW-DQC013-1), the Research Fund Program of Guangdong Provincial Key Laboratory of Marine Resources and Coastal Engineering, and the Youth Program of National Natural Science Foundation of China (41906077).

Institutional Review Board Statement: Not applicable.

Informed Consent Statement: Not applicable.

Data Availability Statement: The sequences generated from the clone library were deposited in GenBank (accession numbers: MW604248-MW604695).

Conflicts of Interest: The authors declare no conflict of interest.

\section{References}

1. Diaz, R.J.; Rosenberg, R. Spreading dead zones and consequences for marine ecosystems. Science 2008, 321, 926-929. [CrossRef] [PubMed]

2. Howarth, R.; Chan, F.; Conley, D.J.; Garnier, J.; Doney, S.C.; Marino, R.; Billen, G. Coupled biogeochemical cycles: Eutrophication and hypoxia in temperate estuaries and coastal marine ecosystems. Front. Ecol. Environ. 2011, 9, 18-26. [CrossRef] 
3. Li, H.; Li, X.; Li, Q.; Liu, Y.; Song, J.; Zhang, Y. Environmental response to long-term mariculture activities in the Weihai coastal area, China. Sci. Total Environ. 2017, 601, 22-31. [CrossRef] [PubMed]

4. Han, Q.; Wang, Y.; Zhang, Y.; Keesing, J.; Liu, D. Effects of intensive scallop mariculture on macrobenthic assemblages in Sishili Bay, the northern Yellow Sea of China. Hydrobiologia 2013, 718, 1-15. [CrossRef]

5. Stramma, L.; Schmidtko, S.; Levin, L.A.; Johnson, G.C. Ocean oxygen minima expansions and their biological impacts. Deep Sea Res. 2010, 57 Pt I, 587-595. [CrossRef]

6. Wright, J.J.; Konwar, K.M.; Hallam, S.J. Microbial ecology of expanding oxygen minimum zones. Nat. Rev. Microbiol. 2012, 10, 381-394. [CrossRef] [PubMed]

7. Crump, B.C.; Peranteau, C.; Beckingham, B.; Cornwell, J.C. Respiratory succession and community succession of bacterioplankton in seasonally anoxic estuarine waters. Appl. Environ. Microbiol. 2007, 73, 6802-6810. [CrossRef]

8. Parsons, R.J.; Nelson, C.E.; Carlson, C.A.; Denman, C.C.; Andersson, A.J.; Kledzik, A.L.; Vergin, K.L.; McNally, S.P.; Treusch, A.H.; Giovannoni, S.J. Marine bacterioplankton community turnover within seasonally hypoxic waters of a subtropical sound: Devil's Hole, Bermuda. Environ. Microbiol. 2015, 17, 3481-3499. [CrossRef]

9. Marañón, E.; Holligan, P.M.; Barciela, R.; González, N.; Mouriño, B.; Pazó, M.J.; Varela, M. Patterns of phytoplankton size structure and productivity in contrasting open-ocean environments. Mar. Ecol. Prog. Ser. 2001, 216, 43-56. [CrossRef]

10. Waterbury, J.B.; Watson, S.W.; Guillard, R.R.; Brand, L.E. Widespread occurrence of a unicellular, marine, planktonic, cyanobacterium. Nature 1979, 277, 293-294. [CrossRef]

11. Scanlan, D.J. Physiological diversity and niche adaptation in marine Synechococcus. Adv. Microb. Physiol. 2003, 47, 1-64. [PubMed]

12. Partensky, F.; Blanchot, J.; Vaulot, D. Differential distribution and ecology of Prochlorococcus and Synechococcus in oceanic waters: A review. Bull. Inst. Oceanogr. Monaco 1999, 19, 457-476.

13. Ahlgren, N.A.; Rocap, G. Culture isolation and culture-independent clone libraries reveal new marine Synechococcus ecotypes with distinctive light and N physiologies. Appl. Environ. Microbiol. 2006, 72, 7193-7204. [CrossRef] [PubMed]

14. Lavin, P.; Gomez, P.; Gonzalez, B.; Ulloa, O. Diversity of the marine picocyanobacteria Prochlorococcus and Synechococcus assessed by terminal restriction fragment length polymorphisms of 16S-23S rRNA internal transcribed spacer sequences. Rev. Chil. Hist. Nat. 2008, 81, 515-531. [CrossRef]

15. Lavin, P.; González, B.; Santibáñez, J.F.; Scanlan, D.J.; Ulloa, O. Novel lineages of Prochlorococcus thrive within the oxygen minimum zone of the eastern tropical South Pacific. Env. Microbiol. Rep. 2010, 2, 728-738. [CrossRef] [PubMed]

16. Huang, S.; Wilhelm, S.W.; Harvey, H.R.; Taylor, K.; Jiao, N.; Chen, F. Novel lineages of Prochlorococcus and Synechococcus in the global oceans. ISME J. 2012, 6, 285-297. [CrossRef] [PubMed]

17. Goericke, R.; Olson, R.J.; Shalapyonok, A. A novel niche for Prochlorococcus sp in low-light suboxic environments in the Arabian Sea and the Eastern Tropical North Pacific. Deep Sea Res. Part I 2000, 47, 1183-1205. [CrossRef]

18. Pajares, S.; Varona-Cordero, F.; Hernández-Becerril, D.U. Spatial distribution patterns of bacterioplankton in the oxygen minimum zone of the tropical Mexican Pacific. Microb. Ecol. 2020, 80, 519-536. [CrossRef]

19. Callieri, C.; Slabakova, V.; Dzhembekova, N.; Slabakova, N.; Peneva, E.; Cabello-Yeves, P.J.; Di Cesare, A.; Eckert, E.M.; Bertoni, R.; Corno, G. The mesopelagic anoxic Black Sea as an unexpected habitat for Synechococcus challenges our understanding of global "deep red fluorescence". ISME J. 2019, 13, 1676-1687. [CrossRef] [PubMed]

20. Yang, B.; Gao, X. Chromophoric dissolved organic matter in summer in a coastal mariculture region of northern Shandong Peninsula, North Yellow Sea. Cont. Shelf Res. 2019, 176, 19-35. [CrossRef]

21. Yang, B.; Gao, X.; Xing, Q. Geochemistry of organic carbon in surface sediments of a summer hypoxic region in the coastal waters of northern Shandong Peninsula. Cont. Shelf Res. 2018, 171, 113-125. [CrossRef]

22. Yang, B.; Gao, X.; Zhao, J.; Liu, Y.; Xie, L.; Lv, X.; Xing, Q. Potential linkage between sedimentary oxygen consumption and benthic flux of biogenic elements in a coastal scallop farming area, North Yellow Sea. Chemosphere 2021, 273, 129641. [CrossRef] [PubMed]

23. Yang, B.; Gao, X.; Zhao, J.; Lu, Y.; Gao, T. Biogeochemistry of dissolved inorganic nutrients in an oligotrophic coastal mariculture region of the northern Shandong Peninsula, north Yellow Sea. Mar. Pollut. Bull. 2020, 150, 110693. [CrossRef]

24. Gong, F.; Li, G.; Wang, Y.; Liu, Q.; Huang, F.; Yin, K.; Gong, J. Spatial shifts in size structure, phylogenetic diversity, community composition and abundance of small eukaryotic plankton in a coastal upwelling area of the northern South China Sea. J. Plankton Res. 2020, 42, 650-667. [CrossRef]

25. Marie, D.; Partensky, F.; Jacquet, S.; Vaulot, D. Enumeration and cell cycle analysis of natural populations of marine picoplankton by flow cytometry using the nucleic acid stain SYBR Green I. Appl. Environ. Microbiol. 1997, 63, 186-193. [CrossRef]

26. Fuchs, B.M.; Zubkov, M.V.; Sahm, K.; Burkill, P.H.; Amann, R. Changes in community composition during dilution cultures of marine bacterioplankton as assessed by flow cytometric and molecular biological techniques. Environ. Microbiol. 2000, 2, 191-201. [CrossRef] [PubMed]

27. Cai, H.; Wang, K.; Huang, S.; Jiao, N.; Chen, F. Distinct patterns of picocyanobacterial communities in winter and summer in the Chesapeake Bay. Appl. Environ. Microbiol. 2010, 76, 2955-2960. [CrossRef]

28. Huber, T.; Faulkner, G.; Hugenholtz, P. Bellerophon: A program to detect chimeric sequences in multiple sequence alignments. Bioinformatics 2004, 20, 2317-2319. [CrossRef]

29. Katoh, K.; Misawa, K.; Kuma, K.I.; Miyata, T. MAFFT: A novel method for rapid multiple sequence alignment based on fast Fourier transform. Nucleic Acids Res. 2002, 30, 3059-3066. [CrossRef] 
30. Stamatakis, A. RAxML-VI-HPC: Maximum likelihood-based phylogenetic analyses with thousands of taxa and mixed models. Bioinformatics 2006, 22, 2688-2690. [CrossRef]

31. Flombaum, P.; Gallegos, J.L.; Gordillo, R.A.; Rincón, J.; Zabala, L.L.; Jiao, N.; Karl, D.M.; Li, W.K.; Lomas, M.W.; Veneziano, D. Present and future global distributions of the marine cyanobacteria Prochlorococcus and Synechococcus. Proc. Natl. Acad. Sci. USA 2013, 110, 9824-9829. [CrossRef]

32. Morel, A. Consequences of a Synechococcus bloom upon the optical properties of oceanic (case 1) waters. Limnol. Oceanogr. 1997, 42, 1746-1754. [CrossRef]

33. Tai, V.; Palenik, B. Temporal variation of Synechococcus clades at a coastal Pacific Ocean monitoring site. ISME J. 2009, 3, 903-915. [CrossRef] [PubMed]

34. Phlips, E.J.; Badylak, S.; Lynch, T.C. Blooms of the picoplanktonic cyanobacterium Synechococcus in Florida Bay, a subtropical inner-shelf lagoon. Limnol. Oceanogr. 1999, 44, 1166-1175. [CrossRef]

35. Millette, N.; Kelble, C.; Linhoss, A.; Ashby, S.; Visser, L. Shift in baseline chlorophyll a concentration following a three-year Synechococcus bloom in southeastern Florida. Bull. Mar. Sci. 2018, 94, 3-19. [CrossRef]

36. Li, J.; Chen, Z.; Jing, Z.; Zhou, L.; Li, G.; Ke, Z.; Jiang, X.; Liu, J.; Liu, H.; Tan, Y. Synechococcus bloom in the Pearl River Estuary and adjacent coastal area-With special focus on flooding during wet seasons. Sci. Total Environ. 2019, 692, 769-783. [CrossRef]

37. Kilham, P.; Hecky, R.E. Comparative ecology of marine and freshwater phytoplankton. Limnol. Oceanogr. 1988, 33, 776-795. [CrossRef]

38. Scanlan, D.J. Marine Picocyanobacteria. In Ecology of Cyanobacteria II: Their Diversity in Space and Time; Springer: Dordrecht, The Netherlands, 2012; pp. 503-533.

39. Hutchins, D.A.; Witter, A.E.; Butler, A.; Luther, G.W. Competition among marine phytoplankton for different chelated iron species. Nature 1999, 400, 858-861. [CrossRef]

40. Proctor, L.M.; Fuhrman, J.A. Viral mortality of marine bacteria and cyanobacteria. Nature 1990, 343, 60-62. [CrossRef]

41. Tsai, A.Y.; Gong, G.C.; Huang, Y.W.; Chao, C.F. Estimates of bacterioplankton and Synechococcus spp. mortality from nanoflagellate grazing and viral lysis in the subtropical Danshui River estuary. Estuar. Coast. Shelf Sci. 2015, 153, 54-61. [CrossRef]

42. Xia, X.; Vidyarathna, N.K.; Palenik, B.; Lee, P.; Liu, H. Comparison of the seasonal variations of Synechococcus assemblage structures in estuarine waters and coastal waters of Hong Kong. Appl. Environ. Microbiol. 2015, 81, 7644-7655. [CrossRef] [PubMed]

43. Xia, X.; Cheung, S.; Endo, H.; Suzuki, K.; Liu, H. Latitudinal and vertical variation of Synechococcus assemblage composition along 170 degrees W transect from the South Pacific to the Arctic Ocean. Microb. Ecol. 2019, 77, 333-342. [CrossRef] [PubMed]

44. Kim, Y.; Jeon, J.; Kwak, M.S.; Kim, G.H.; Koh, I.; Rho, M. Photosynthetic functions of Synechococcus in the ocean microbiomes of diverse salinity and seasons. PLoS ONE 2018, 13, e0190266. [CrossRef] [PubMed]

45. Dufresne, A.; Ostrowski, M.; Scanlan, D.J.; Garczarek, L.; Mazard, S.; Palenik, B.P.; Paulsen, I.T.; de Marsac, N.T.; Wincker, P.; Dossat, C. Unraveling the genomic mosaic of a ubiquitous genus of marine cyanobacteria. Genome Biol. 2008, 9, R90. [CrossRef] [PubMed]

46. Jing, H.; Liu, H.; Suzuki, K. Phylogenetic diversity of marine Synechococcus spp. in the Sea of Okhotsk. Aquat. Microb. Ecol. 2009, 56, 55-63. [CrossRef]

47. Zwirglmaier, K.; Jardillier, L.; Ostrowski, M.; Mazard, S.; Garczarek, L.; Vaulot, D.; Not, F.; Massana, R.; Ulloa, O.; Scanlan, D.J. Global phylogeography of marine Synechococcus and Prochlorococcus reveals a distinct partitioning of lineages among oceanic biomes. Environ. Microbiol. 2008, 10, 147-161. [CrossRef] [PubMed]

48. Zwirglmaier, K.; Heywood, J.L.; Chamberlain, K.; Woodward, E.M.S.; Zubkov, M.V.; Scanlan, D.J. Basin-scale distribution patterns lineages in the Atlantic Ocean. Environ. Microbiol. 2007, 9, 1278-1290. [CrossRef]

49. Chen, F.; Wang, K.; Kan, J.; Suzuki, M.T.; Wommack, K.E. Diverse and unique picocyanobacteria in Chesapeake Bay, revealed by 16S-23S rRNA internal transcribed spacer sequences. Appl. Environ. Microbiol. 2006, 72, 2239-2243. [CrossRef]

50. Choi, D.H.; Noh, J.H. Phylogenetic diversity of Synechococcus strains isolated from the East China Sea and the East Sea. FEMS Microbiol. Ecol. 2009, 69, 439-448. [CrossRef]

51. Sohm, J.A.; Ahlgren, N.A.; Thomson, Z.J.; Williams, C.; Moffett, J.W.; Saito, M.A.; Webb, E.A.; Rocap, G. Co-occurring Synechococcus ecotypes occupy four major oceanic regimes defined by temperature, macronutrients and iron. ISME J. 2016, 10, 333-345. [CrossRef]

52. Pittera, J.; Humily, F.; Thorel, M.; Grulois, D.; Garczarek, L.; Six, C. Connecting thermal physiology and latitudinal niche partitioning in marine Synechococcus. ISME J. 2014, 8, 1221-1236. [CrossRef] [PubMed]

53. Sliwinska-Wilczewska, S.; Maculewicz, J.; Felpeto, A.B.; Vasconcelos, V.; Latala, A. Allelopathic activity of picocyanobacterium Synechococcus sp on filamentous cyanobacteria. J. Exp. Mar. Biol. Ecol. 2017, 496, 16-21. [CrossRef]

54. Sliwinska-Wilczewska, S.; Felpeto, A.B.; Maculewicz, J.; Sobczyk, A.; Vasconcelos, V.; Latala, A. Allelopathic activity of the picocyanobacterium Synechococcus sp on unicellular eukaryote planktonic microalgae. Mar. Freshwater Res. 2018, 69, 1472-1479. [CrossRef]

55. Bubak, I.; Śliwińska-Wilczewska, S.; Głowacka, P.; Szczerba, A.; Możdżeń, K. The importance of allelopathic picocyanobacterium Synechococcus sp. on the abundance, biomass formation, and structure of phytoplankton assemblages in three freshwater lakes. Toxins 2020, 12, 259. [CrossRef] 